\title{
Polish haematology: looking to the future
}

\author{
Wiesław Wiktor Jędrzejczak \\ Department of Haematology, Transplantation and Internal Medicine, Medical University of Warsaw, Warsaw, Poland
}

In this issue, Giebel et al. [1] report on the status of haemato-oncology in Poland. They summarise achievements and describe its current situation. Polish haematology is most certainly at a crossroads. There has been a changing of the guard. Within just a few years, the 'baby boomer' generation (those born shortly after World War II) has transferred practically all chair positions to a younger generation of doctors born in the late 1960s and the 1970s. This is the generation whose careers began after the change of Poland's political and economic system. This generation will be responsible for developments in the field over the next 20-30 years.

Since the start of the $21^{\text {st }}$ century, the number of Polish haematologists has more than doubled, reaching now almost 500 fully trained specialists, with more than 100 in training. There are haematology centres in all regions (previously almost half of Poland's 16 voivodships had none) but the greatest challenge is the rapidly growing number of patients. This is due to the ageing of society and even more so to the increased effectiveness of therapy. Progress in haematology which now is almost instantaneously incorporated into practice is generating more and more people surviving with chronic disease who need services.

An interesting analysis of the survival of patients with various cancers was published by the Polish National Institute of Public Health. The overall effects of cancer treatment in Poland are inferior when compared to the countries of what we used to call 'Western Europe'. However, there is one exception: leukemia. Poland, while not leading, is not far behind these latter countries [2]. Poland is one of the few countries in which bone marrow transplantation technology was independently developed, rather than being imported from abroad [3-6]. While this was largely due to necessity (development took place in the early 1980s when Poland was under martial law and foreign travel was not permitted), this is a clear demonstration of the innovative potential of Polish haematology.
Today, Poland has nearly closed the gap in the number of haematopoietic cell transplantations $(1,848$ transplantations in 2019) between it and more developed countries, and has become a 'superpower' in terms of the number of registered potential donors of haematopoietic cells (almost 1.8 million registered and typed people). This is a figure exceeded only by the US, Germany, and Brazil. Moreover, Poland has become the second of only two countries (the first being Germany) to provide more transplants to foreign patients than to its own (1,294 vs. 265 in 2019) [7, 8].

While Polish haematology centres participate actively in global clinical trials, there is still a limited number of trials initiated and designed in Poland. The Polish pharmaceutical industry is concentrated on the production of generic drugs, and the next step should include also some innovative molecules. However, these have to be invented or discovered by the chemists!

The successful introduction of Polish-made cladribine has shown that Polish haematology is capable of designing and performing trials with the aim of introducing new drugs to clinical practice, when gaining early access to new molecules $[9,10]$. Polish haematology is well integrated into European haematology, with Polish centres being very active in the European Leukemia Net, the European Haematology Association, and the European Society for Blood and Marrow Transplantation.

The future depends both on encouraging further research in Poland, and actively participating in international collaboration.

\section{Authors' contributions \\ WWJ - sole author.}

\section{Conflict of interest}

None.

\section{Financial support}

None.
Address for correspondence: Wiesław Wiktor Jędrzejczak, Department

of Haematology, Transplantation and Internal Medicine, Medical

University of Warsaw, Banacha 1A, 02-097 Warsaw, Poland, phone: +48 2259928 18, e-mail: wieslaw.jedrzejczak@wum.edu.pl
PTHiT Copyright $\odot 2021$

The Polish Society of Haematologists and Transfusiologists,

Insitute of Haematology and Transfusion Medicine.

All rights reserved. 


\section{Ethics}

The work described in this article has been carried out in accordance with The Code of Ethics of the World Medical Association (Declaration of Helsinki) for experiments involving humans; EU Directive 2010/63/EU for animal experiments; Uniform requirements for manuscripts submitted to biomedical journals.

\section{References}

1. Giebel S, Basak G, Bieniaszewska M, et al. Current status and progress of Polish haemato-oncology. Acta Haematol Pol. 2021; 52(1): 4-17, doi: 10.5603/AHP.2021.0003.

2. Kwiatkowska K, Bogusz J, Dudek-Godeau D, Bielska-Lasota M. Poprawa wyleczalności chorych na niektóre nowotwory złośliwe w Polsce w latach 2000-2009. In: Wojtyniak B, Goryński P. ed. Sytuacja zdrowotna ludności polski i jej uwarunkowania. Narodowy Instytut Zdrowia Publicznego - Państwowy Zakład Higieny, Warszawa 2016: 161-171.

3. Jedrzejczak WW, Pojda Z. Bone marrow transplantation in Polish conditions. A modified method of marrow collection and preparation for transplantation. Arch Immunol Ther Exp (Warsz). 1987; 35: 79-86.

4. Ratajczak MZ, Jędrzejczak WW. Elimination of red blood cells from marrow inoculum using centrifugation on a gradient of polysaccharide and ditrizoate prior blood group incompatible bone marrow transplantation (Polish). Pol Tyg Lek. 1987; 42: 907-910.

5. Jedrzejczak WW, Szczylik C, Pojda Z. Success of bone marrow transplantation in congenital Diamond-Blackfan anemia: a case report. Eur J Haematol. 1987; 38: 204-206.

6. Jedrzejczak WW, Szczylik C, Matej H, et al. Allogeneic bone marrow transplantation from HLA identical siblings following conditioning with busulphan and cyclophosphamide. First results. Folia Haematol Int Mag Klin Morphol Blutforsch. 1989; 116(3-4): 403-408, indexed in Pubmed: 2480281.

7. Rejestr przeszczepień komórek krwiotwórczych szpiku, krwi obwodowej oraz krwi pępowinowe. Biuletyn informacyjny. Poltransplant. 2020; 29(1): 42-49.

8. Wywóz i przywóz do Polski narządów I komórek krwiotwórczych. Biuletyn informacyjny. Poltransplant. 2020; 29(1): 89-92.

9. Robak T, Jamroziak K, Gora-Tybor J, et al. Comparison of cladribine plus cyclophosphamide with fludarabine plus cyclophosphamide as first-line therapy for chronic lymphocytic leukemia: a phase III randomized study by the Polish Adult Leukemia Group (PALG-CLL3 Study). J Clin Oncol. 2010; 28(11): 1863-1869, doi: 10.1200/ /JC0.2009.25.9630, indexed in Pubmed: 20212251.

10. Holowiecki J, Grosicki S, Giebel S, et al. Cladribine, but not fludarabine, added to daunorubicin and cytarabine during induction prolongs survival of patients with acute myeloid leukemia: a multicenter, randomized phase III study. J Clin Oncol. 2012; 30(20): 2441-2448, doi: 10.1200/JC0.2011.37.1286, indexed in Pubmed: 22508825. 